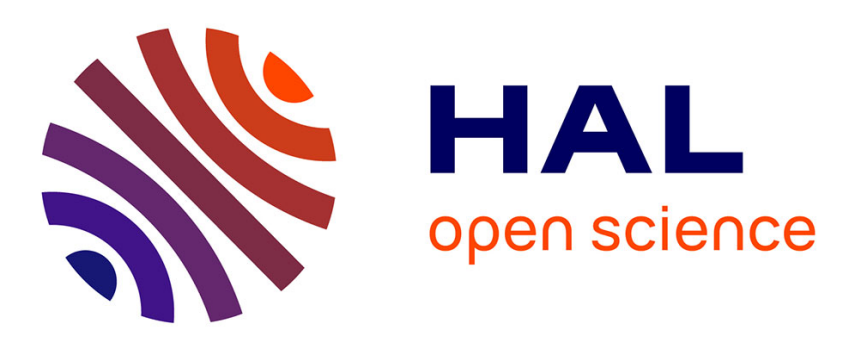

\title{
Phase evolution of a barium tin 1,2-ethanediolato complex to barium stannate during thermal decomposition
}

Roberto Köferstein, Hans-Peter Abicht, Jörg Woltersdorf, Eckhard Pippel

\section{- To cite this version:}

Roberto Köferstein, Hans-Peter Abicht, Jörg Woltersdorf, Eckhard Pippel. Phase evolution of a barium tin 1,2-ethanediolato complex to barium stannate during thermal decomposition. Thermochimica Acta, 2007, 441 (2), pp.176-183. 10.1016/j.tca.2005.12.010 . hal-01995132

\section{HAL Id: hal-01995132 \\ https://hal.science/hal-01995132}

Submitted on 25 Jan 2019

HAL is a multi-disciplinary open access archive for the deposit and dissemination of scientific research documents, whether they are published or not. The documents may come from teaching and research institutions in France or abroad, or from public or private research centers.
L'archive ouverte pluridisciplinaire HAL, est destinée au dépôt et à la diffusion de documents scientifiques de niveau recherche, publiés ou non, émanant des établissements d'enseignement et de recherche français ou étrangers, des laboratoires publics ou privés. 


\title{
Thermochimica Acta 441 (2006) 176-183 \\ (doi:10.1016/j.tca.2005.12.010) \\ http://dx.doi.org/10.1016/j.tca.2005.12.010
}

\section{Phase evolution of a barium tin 1,2-ethanediolato complex to barium stannate during thermal decomposition}

\author{
Roberto Köferstein ${ }^{\text {a }}$, Hans-Peter Abicht ${ }^{a} *$, Jörg Woltersdorf ${ }^{b}$, Eckhard Pippel $^{b}$ \\ ${ }^{a}$ Fachbereich Chemie, Martin-Luther-Universität Halle-Wittenberg, \\ Kurt-Mothes Str. 2, D-06120 Halle, Germany \\ ${ }^{b}$ Max-Planck-Institut für Mikrostrukturphysik, Weinberg 2, D-06120 Halle, Germany \\ * Corresponding author. Tel.: +49-345-5525622; fax: +49-345-5527028. \\ E-mail address: hans-peter.abicht@chemie.uni-halle.de
}

\begin{abstract}
The thermal behaviour of $\left[\mathrm{Ba}\left(\mathrm{C}_{2} \mathrm{H}_{6} \mathrm{O}_{2}\right)_{4}\right]\left[\mathrm{Sn}\left(\mathrm{C}_{2} \mathrm{H}_{4} \mathrm{O}_{2}\right)_{3}\right]$ used as a $\mathrm{BaSnO}_{3}$ precursor, and its phase evolution during thermal decomposition are described. The initially formed transient barium-tin-oxycarbonate phase disintegrates into $\mathrm{BaCO}_{3}$ and $\mathrm{SnO}_{2}$, reacting subsequently to $\mathrm{BaSnO}_{3}$. The existence of the intermediate oxycarbonate phase is evidenced by FT-IR, XRD, and EELS (ELNES) investigations.
\end{abstract}

Keywords: Barium stannate; 1,2-ethanediolato complex; oxycarbonate phase; thermal decomposition.

\section{Introduction}

Barium stannate and its solid solutions of the type $\mathrm{Ba}(\mathrm{Ti}, \mathrm{Sn}) \mathrm{O}_{3}$ have found important applications in materials science and technology due to their dielectric properties, 
enabling the fabrication of ceramic boundary layer capacitors and multifunctional signal sensors to detect temperatures and gases [1-4]. Moreover, $\mathrm{Ba}(\mathrm{Ti}, \mathrm{Sn}) \mathrm{O}_{3}$ solid solutions may be considered as model systems for $\mathrm{Pb}$-free perovskites revealing diffuse ferroelectric phase transitions [5]. The preparation of $\mathrm{BaSnO}_{3}$ powder using the conventional mixed oxide method requires temperatures above $1200{ }^{\circ} \mathrm{C}$ [6]. Some authors reported preparations of $\mathrm{BaSnO}_{3}$ by hydrothermal methods or sol-gel processes which are possible at relatively low temperatures of 260 to $330{ }^{\circ} \mathrm{C}$ [8-12]. A peroxide method to synthesis phase pure $\mathrm{BaSnO}_{3}$ is reported by Pfaff [13]. Gallagher [14] described the preparation of $\mathrm{BaSnO}_{3}$ by the thermal decomposition of a barium tin(IV) oxalate precursor at temperatures below $1000{ }^{\circ} \mathrm{C}$. Thermal treatment of a polymeric complex, prepared by a modified Pechini process [15] leads also to microcrystalline $\mathrm{BaSnO}_{3}[16]$. The advantage of the thermal decomposition of barium tin (IV) precursors is not only the lower calcination temperature, but also the calcination process leads to preceramic powders with particles sizes in the nanometer range.

In [17] we reported on the preparation and structure of the precursor complex $\left(\left[\mathrm{Ba}\left(\mathrm{C}_{2} \mathrm{H}_{6} \mathrm{O}_{2}\right)_{4}\right]\left[\mathrm{Sn}\left(\mathrm{C}_{2} \mathrm{H}_{4} \mathrm{O}_{2}\right)_{3}\right]\right.$ and its conversion into $\mathrm{BaSnO}_{3}$. Our investigations showed that $\left[\mathrm{Ba}\left(\mathrm{C}_{2} \mathrm{H}_{6} \mathrm{O}_{2}\right)_{4}\right]\left[\mathrm{Sn}\left(\mathrm{C}_{2} \mathrm{H}_{4} \mathrm{O}_{2}\right)_{3}\right]$ and the isotypic compound $\left[\mathrm{Ba}\left(\mathrm{C}_{2} \mathrm{H}_{6} \mathrm{O}_{2}\right)_{4}\right]\left[\mathrm{Ti}\left(\mathrm{C}_{2} \mathrm{H}_{4} \mathrm{O}_{2}\right)_{3}\right]$ are suitable to form mixed solid solutions of the type $\left[\mathrm{Ba}\left(\mathrm{C}_{2} \mathrm{H}_{6} \mathrm{O}_{2}\right)_{4}\right]\left[\mathrm{Ti}_{1-\mathrm{x}} \mathrm{Sn}_{\mathrm{x}}\left(\mathrm{C}_{2} \mathrm{H}_{4} \mathrm{O}_{2}\right)_{3}\right]$, which can be decomposed to phase pure $\mathrm{Ba}(\mathrm{Ti}, \mathrm{Sn}) \mathrm{O}_{3}$ powders [18]. In these mixed $\mathrm{Ba}(\mathrm{Ti}, \mathrm{Sn})$ precursor complexes the stoichiometry and the distribution of all components are already adapted to a molecular scale with respect to the following calcination and phase formation processes, so that a homogeneous tin distribution can be achieved. In contrast, the preparation of $\mathrm{Ba}(\mathrm{Ti}, \mathrm{Sn}) \mathrm{O}_{3}$ by the classical solid state reaction leads to ceramics with an inhomogeneous tin distribution [7]. 
To understand the formation of $\mathrm{BaSnO}_{3}$ by the thermal decomposition of $\left[\mathrm{Ba}\left(\mathrm{C}_{2} \mathrm{H}_{6} \mathrm{O}_{2}\right)_{4}\right]\left[\mathrm{Sn}\left(\mathrm{C}_{2} \mathrm{H}_{4} \mathrm{O}_{2}\right)_{3}\right]$ it is important to investigate the thermal behavior of this complex.

Here we describe in detail the phase evolution during thermal decomposition of the precursor complex yielding finally $\mathrm{BaSnO}_{3}$ with special regard to the intermediate oxycarbonate phase. To our best knowledge, until now the thermal decomposition of barium tin(IV) precursors yielding finally $\mathrm{BaSnO}_{3}$ are reported only by Gallagher [14]. In this paper was described the formation of mixed highly reactive $\mathrm{BaCO}_{3}$ and $\mathrm{SnO}_{2}$ only as an intermediate step during the thermal decomposition of barium tin(IV) oxalate.

Contrary to this, the thermal decomposition of (Ba,Ti)-organic precursors is very well investigated. During the thermolysis of $(\mathrm{Ba}, \mathrm{Ti})$-precursors an intermediate product of the gross formula $\mathrm{Ba}_{2} \mathrm{Ti}_{2} \mathrm{O}_{5} \mathrm{CO}_{3}$ can be observed [19-29]. $\mathrm{BaTiO}_{3}$ is formed directly by the thermal decomposition of this intermediate phase. The existence of an oxycarbonate intermediate phase during the thermal decomposition of barium titanyl oxalate was pointed out first by Gopalagrishnamurthy et al. [19]. The existence and the true nature of this intermediate phase has been discussed controversially. Vasyl'kiv et al. [20] described the nature of the intermediate phase as a mixture of amorphous $\mathrm{TiO}_{2}, \mathrm{BaO}$ and $\mathrm{BaCO}_{3}$. Hennings et al. [21] described this phase as a mixture of $\mathrm{TiO}_{2}$ and $\mathrm{BaCO}_{3}$ in finest distribution, whereas Cho [24] concluded, that the intermediate phase is not a barium titanium oxycarbonate but hexagonal $\mathrm{BaTiO}_{3}$ stabilized with $\mathrm{Ti}^{3+}$. Tsay et al [22] reported that the structure of the metastable phase might possess the structure of $\mathrm{BaTiO}_{3}$ with carbonate ions deposited within the barium titanate layers.

From TG/DTA, IR , X-ray powder diffraction and EELS investigations Kumar et al. [27], Gablenz et al [28], Duran et al.[29] concluded that the intermediate is a unique, although weakly crystalline, oxycarbonate phase having the formula $\mathrm{Ba}_{2} \mathrm{Ti}_{2} \mathrm{O}_{5} \mathrm{CO}_{3}$. 
The formation of such an intermediate product is dependent on the heating rate [30].

Waser et al. [31,32] reported, that an appearance of a carbon-rich intermediate phase, like $\mathrm{Ba}_{2} \mathrm{Ti}_{2} \mathrm{O}_{5} \mathrm{CO}_{3}$, delays the crystallization process to higher temperatures and leads to a better densification of thin films. Therefore the knowledge about such intermediate phases are important with respect to technical problems.

The existence of intermediate oxycarbonate phases is observed during the thermal decomposition of other precursors, too. Leite et al. [33] have evidenced the existence of an $\mathrm{Sr}_{2} \mathrm{Ti}_{2} \mathrm{O}_{5} \mathrm{CO}_{3}$ intermediate during the preparation of $\mathrm{SrTiO}_{3}$ via the Pechini process [15]. During the thermal decomposition of some lanthanoide oxalates oxycarbonate phases of the type $L n_{2} \mathrm{O}_{2+x}\left(\mathrm{CO}_{3}\right)_{1-x}$ can be observed, too [34-37]. Krupicka et al. [38] have evidenced $\mathrm{La}_{2} \mathrm{O}_{2} \mathrm{CO}_{3}$ and $\mathrm{NiO}$ as an intermediate step during the synthesis of $\mathrm{LaNiO}_{3}$.

\section{Experimental}

\subsection{Material preparation}

We have described the preparation procedure for $\left[\mathrm{Ba}\left(\mathrm{C}_{2} \mathrm{H}_{6} \mathrm{O}_{2}\right)_{4}\right]\left[\mathrm{Sn}\left(\mathrm{C}_{2} \mathrm{H}_{4} \mathrm{O}_{2}\right)_{3}\right]$ in $[17,18]$. Briefly, to a solution of $\mathrm{SnCl}_{4}(26 \mathrm{~g}, 0.10 \mathrm{~mol}$; Laborchemie Apolda) in water (1000 mL), ammonia solution was added to adjust $\mathrm{pH}$ 7. The precipitate was washed with cold water ( 8 times) by repeated decanting of the clear solution and addition of the same volume of water. Thereafter the solid $\left(\mathrm{SnO}_{2} \cdot n \mathrm{H}_{2} \mathrm{O}\right)$ was filtered off. A suspension of wet $\mathrm{SnO}_{2} \cdot n \mathrm{H}_{2} \mathrm{O}(0.1 \mathrm{~mol}), \mathrm{Ba}(\mathrm{OH})_{2} \cdot 8 \mathrm{H}_{2} \mathrm{O}(31.6 \mathrm{~g}, 0.1 \mathrm{~mol}$; Fluka) in $1000 \mathrm{~mL}$ 1,2-ethanediol was heated under reflux for $24 \mathrm{~h}$. About $500 \mathrm{~mL}$ of the solvent were removed under normal pressure and, afterwards, about $200 \mathrm{~mL}$ under reduced pressure. The reaction mixture was cooled, diluted with $100 \mathrm{~mL}$ of acetone and filtered off. The crystalline precipitate of $\left[\mathrm{Ba}\left(\mathrm{C}_{2} \mathrm{H}_{6} \mathrm{O}_{2}\right)_{4}\right]\left[\mathrm{Sn}\left(\mathrm{C}_{2} \mathrm{H}_{4} \mathrm{O}_{2}\right)_{3}\right]$ was washed with acetone. 
Analysis: $\mathrm{C}_{14} \mathrm{H}_{36} \mathrm{O}_{14} \mathrm{BaSn}(684.5 \mathrm{~g} / \mathrm{mol})$ : calc. C, $24.57 \%$; H, $5.30 \%$, found C, 24.21; $\mathrm{H}, 5.47 \%$.

The phases evolution during the thermal decomposition of $\left[\mathrm{Ba}\left(\mathrm{C}_{2} \mathrm{H}_{6} \mathrm{O}_{2}\right)_{4}\right]\left[\mathrm{Sn}\left(\mathrm{C}_{2} \mathrm{H}_{4} \mathrm{O}_{2}\right)_{3}\right]$ was studied on samples, heated at various temperatures up to $1000{ }^{\circ} \mathrm{C}$ in a muffle furnace at static air.

\subsection{Analytical methods}

The Fourier transformed infrared (FT-IR) spectra were collected using a Mattson 5000 spectrometer (Mattson Instruments Inc.) in the range of $400-4000 \mathrm{~cm}^{-1}$ with resolution of $2 \mathrm{~cm}^{-1}$ as $\mathrm{KBr}$ pellets. X-ray powder diffraction (XRD) pattern were recorded at 25 ${ }^{\circ} \mathrm{C}$ and performed by a STADI MP diffractometer from STOE with a curved crystal germanium monochromator using $\mathrm{CoK} \alpha_{1}$ radiation and a degree step of $0.03^{\circ}$ for $2 \theta$. Simultaneous thermogravimetric (TG) and differential thermoanalytic (DTA) measurements were achieved using an STA 449C from Netzsch (Germany) (heating rate $10 \mathrm{~K} / \mathrm{min}$; flowing air (Pt crucible) with $20 \mathrm{~mL} / \mathrm{min}$ and flowing argon $\left(\mathrm{Al}_{2} \mathrm{O}_{3}\right.$ crucible) with $50 \mathrm{~mL} / \mathrm{min}$ ). Simultaneous DTA/TG and MS (mass spectrometry) investigations were accomplished by a STA 409CD (DTA/TG) with Skimmer coupling from Netzsch (Germany), equipped with a quadrupole mass spectrometer, QMA 400, from Balzers. The specific surface area was measured using nitrogen three-point BET (Nova 1000, Quantachrome Corporation, USA).

EELS (electron energy loss spectroscopy) measurements were performed in a transmission electron microscope (Philips CM20 FEG TEM/STEM) operated at 200 $\mathrm{keV}$ and equipped with a post-column electron energy filter (Gatan Imaging Filter GIF 200, model 667). An analyser CHNS 932 (LECO Instruments GmbH) was used for elemental analyses. 


\section{Results and discussion}

\subsection{Thermal behaviour}

Fig. 1 and 2 show the TG and DTA curves for $\left[\mathrm{Ba}\left(\mathrm{C}_{2} \mathrm{H}_{6} \mathrm{O}_{2}\right)_{4}\right]\left[\mathrm{Sn}\left(\mathrm{C}_{2} \mathrm{H}_{4} \mathrm{O}_{2}\right)_{3}\right]$ in air and in argon atmosphere, respectively. The thermal behaviour of the precursor in air has been described in previous papers $[17,18]$. For a better understanding for the following results we summarize the DTA/TG results in air again.

An endothermic reaction between 125 and $160{ }^{\circ} \mathrm{C}$ leads to a weight loss of $24.7 \%$. The DTA curve shows an exothermic peak between 195 and $232{ }^{\circ} \mathrm{C}$. The total weight loss up to $323{ }^{\circ} \mathrm{C}$ is $36.2 \%$ in accordance with the loss of four 1,2-ethanediol molecules per formula unit (calc. $36.3 \%$ ). Between about $334-350{ }^{\circ} \mathrm{C}$ and $350-414{ }^{\circ} \mathrm{C}$ two exothermic peaks can be observed, which are caused a weight loss of $9.0 \%$. This level is not stable, a following weight loss of $4.1 \%$ up to $464{ }^{\circ} \mathrm{C}$ correlates with a strong exothermic effect, which leads to the formation of $\mathrm{BaCO}_{3}$ and $\mathrm{SnO}_{2}$. This level is stable up to about $670{ }^{\circ} \mathrm{C}$. Further weight losses up to $875^{\circ} \mathrm{C}$ lead to a pure $\mathrm{BaSnO}_{3}$ phase. The total weight loss of $55.4 \%$ corresponds well with the theoretical value $(55.6 \%)$. TG/DTA measurement in air with a heating rate of $1 \mathrm{~K} / \mathrm{min}$ shows that up to $681{ }^{\circ} \mathrm{C}$ the barium tin precursor is completely transformed into $\mathrm{BaSnO}_{3}$.

The TG/DTA investigation in argon atmosphere shows two endothermic peaks between about $134-201{ }^{\circ} \mathrm{C}$ and $201-237{ }^{\circ} \mathrm{C}$. The weight loss under those endothermic peaks corresponds to the loss of the solvate molecules. The resulted desolvated compound is stable up to $330{ }^{\circ} \mathrm{C}$. A following exothermic process up to ca. $398^{\circ} \mathrm{C}$ caused a weight loss of about $12.3 \%$. Afterwards weight losses up to about $840{ }^{\circ} \mathrm{C}$ leads to the formation of pure $\mathrm{BaSnO}_{3}$. The total weight loss of $54.0 \%$ differs a little from the theoretical value $(55.6 \%)$.

DTA/TG-MS measurements in helium atmosphere showed the typical MS pattern of 1,2-ethanediol accompanied by $\mathrm{CO}, \mathrm{H}_{2} \mathrm{O}$ and may be acetylene. DTA/TG-MS 
investigation in air showed peaks at $\mathrm{m} / \mathrm{z}=14,28,32,40$ and 44 . The most intensive peak at $\mathrm{m} / \mathrm{z}=28$ corresponds to $\mathrm{CO}$ and may be ethylene.

\section{$<$ Graphic 1 and $2>$}

The development of the specific surface area depending on the calcination temperature is shown in Fig. 3. The slightly increasing of the specific surface area up to $300{ }^{\circ} \mathrm{C}$ suggest, that no major structural changes are involved during the lost of the 1,2ethanediol molecules around barium (desolvation process). The increasing in specific surface area up to about $400{ }^{\circ} \mathrm{C}$ results from the decomposition of the desolvated level $\left(\mathrm{Ba}\left[\mathrm{Sn}\left(\mathrm{C}_{2} \mathrm{H}_{4} \mathrm{O}_{2}\right)_{3}\right]\right)$. The decomposition leads to the formation of a large number of product particles not only by the evolution of gas, but also by the different densities and the molar volumes of barium tin 1,2-ethandiolate $\left(\rho \sim 2 \mathrm{~g} / \mathrm{cm}^{3}\right)$ and the formed compounds $\mathrm{BaCO}_{3}$ and $\mathrm{SnO}_{2}\left(\rho \sim 4-7 \mathrm{~g} / \mathrm{cm}^{3}\right)$. This great difference between the densities leads to strains within the crystallites during the transformation, so that the crystallites will disintegrate into very large number of particles [39-41]. Up to about 800 ${ }^{\circ} \mathrm{C}$ the specific surface area fell to a minimum, whereas the TG curve showed several mass losses in this temperature range. The process of decomposition which leads to a larger specific surface area will be opposed by sintering process. Further increasing in specific surface area from about $800-900{ }^{\circ} \mathrm{C}$ is caused by the reaction between $\mathrm{BaCO}_{3}$ and $\mathrm{SnO}_{2}$ to $\mathrm{BaSnO}_{3}$. From $900{ }^{\circ} \mathrm{C}$ it can be observed a decreasing in specific surface area of the resulting particles. The range between $900{ }^{\circ} \mathrm{C}$ and $1000{ }^{\circ} \mathrm{C}$ corresponds to the Tammann number of $\sim 0.5-0.6$, so that the sintering process in this range is caused by lattice diffusion [42-47]. 


\subsection{X-ray powder diffraction (XRD) and IR spectroscopy}

The XRD pattern of the $\left[\mathrm{Ba}\left(\mathrm{C}_{2} \mathrm{H}_{6} \mathrm{O}_{2}\right)_{4}\right]\left[\mathrm{Sn}\left(\mathrm{C}_{2} \mathrm{H}_{4} \mathrm{O}_{2}\right)_{3}\right]$ precursor (Fig. 4a) shows the well developed crystalline state of the powder and confirms that the powder is a single phase in accordance with the single crystal structure analysis [17].

The IR spectrum of the precursor is shown in Fig. $4 \mathrm{~b}$, revealing a broad band between about $3500-3000 \mathrm{~cm}^{-1}$, which is caused by $\mathrm{O}-\mathrm{H}$ stretching vibrations. The bands between $2915-2830 \mathrm{~cm}^{-1}$ are assigned to the stretching vibration of the $\mathrm{C}-\mathrm{H}$ groups. A broad peak at about $1635 \mathrm{~cm}^{-1}$ is probably due to water adsorbed to the $\mathrm{KBr}$. In the range between $1500-1200 \mathrm{~cm}^{-1}$ the adsorption bands for $\mathrm{CH}_{2}$ deformation vibrations can be observed, where band at $1456 \mathrm{~cm}^{-1}$ is assigned to the $\mathrm{CH}_{2}$ bending mode. The $\mathrm{CH}_{2}$ wagging vibration is observed at $1342 \mathrm{~cm}^{-1}$ and the $\mathrm{CH}_{2}$ twisting modes could be assigned at 1238 and $1215 \mathrm{~cm}^{-1}$ [48,49]. The $\mathrm{C}-\mathrm{O}$ stretching vibration is presented by two strong bands at 1083 and $1051 \mathrm{~cm}^{-1}$. Normal-coordinate calculations have suggested, mode mixing among the $\mathrm{C}-\mathrm{O}$ stretching, $\mathrm{C}-\mathrm{C}$ stretching and $\mathrm{CH}_{2}$ rocking vibrations in the gauche conformation of 1,2-ethanediol [50,51]. Therefore two strong $\mathrm{C}-\mathrm{O}$ stretching bands are expected for the gauche conformation [52]. The single crystal structure analysis of $\left[\mathrm{Ba}\left(\mathrm{C}_{2} \mathrm{H}_{6} \mathrm{O}_{2}\right)_{4}\right]\left[\mathrm{Sn}\left(\mathrm{C}_{2} \mathrm{H}_{4} \mathrm{O}_{2}\right)_{3}\right]$ shows clearly the gauche-like conformation of the 1,2-ethanediol molecules [17]. The band at $888 \mathrm{~cm}^{-1}$ is assigned to the $\mathrm{CH}_{2}$ rocking mode $[48,49]$. $\mathrm{Sn}-\mathrm{O}$ vibrations are manifested in the range between about $600-450 \mathrm{~cm}^{-1}[53,54]$. 
$<$ Graphic 4 >

\subsection{Phase evolution during the thermal decomposition}

\subsubsection{IR spectroscopy}

Fig. 5 shows that the IR spectrum of a sample heated at $300{ }^{\circ} \mathrm{C}$ is similar to the spectrum of the $\left[\mathrm{Ba}\left(\mathrm{C}_{2} \mathrm{H}_{6} \mathrm{O}_{2}\right)_{4}\right]\left[\mathrm{Sn}\left(\mathrm{C}_{2} \mathrm{H}_{4} \mathrm{O}_{2}\right)_{3}\right]$ precursor at room temperature, only heating above $300{ }^{\circ} \mathrm{C}$ leads to a significant change in the IR spectra. At further heating, the typical vibrations modes for the precursor disappeared and bands corresponding to orthorhombic $\mathrm{BaCO}_{3}$ appeared $\left(1752\left(v_{\mathrm{s}}+\delta_{\text {oop }}\right), 1435\left(v_{\mathrm{as}}\right), 1060\left(v_{\mathrm{s}}\right), 858\left(\delta_{\text {oop }}\right)\right.$ and $\left.692\left(\delta_{\text {ip }}\right) \mathrm{cm}^{-1}\right)$ [55]. At a calcination temperature at $400{ }^{\circ} \mathrm{C}$ an extra peak at $872 \mathrm{~cm}^{-1}$ (inset in Fig. 5b) can be observed. A comparison of the vibration modes of the $\mathrm{CO}_{3}{ }^{2-}$ ions in $\mathrm{CaCO}_{3}, \mathrm{SrCO}_{3}$ and $\mathrm{BaCO}_{3}$ showed, that especially the position of the out-ofplane vibration is dependent on the crystallographic environment of the carbonate ion (site symmetry). For example, the out-of-plane vibration shifts to higher wavenumbers by the transition from orthorhombic aragonite to trigonal calcite $[28,44]$. That means, the appearance of a peak at $872 \mathrm{~cm}^{-1}$ indicates the existence of an intermediate carbonate phase (e.g. oxycarbonate phase), which does not correspond to orthorhombic $\mathrm{BaCO}_{3}$. Gablenz et al. [28], Duran et al. [29], and Gopalagrishnamurthy et al. [19] observed the appearance of the infrared bands of orthorhombic $\mathrm{BaCO}_{3}$ also for the thermal decomposition of barium titanium organic precursors (formation of $\mathrm{Ba}_{2} \mathrm{Ti}_{2} \mathrm{O}_{5} \mathrm{CO}_{3}$ ), however the out-of-plane vibration mode at $858 \mathrm{~cm}^{-1}$ was shifted to 875 $\mathrm{cm}^{-1}$. At $500{ }^{\circ} \mathrm{C}$ the extra peak at $872 \mathrm{~cm}^{-1}$ disappears, only bands for orthorhombic $\mathrm{BaCO}_{3}$ and $\mathrm{SnO}_{2}$ are observed. Heating at $800{ }^{\circ} \mathrm{C}$ results in the formation of $\mathrm{BaSnO}_{3}$ by an intensive broad peak at $660 \mathrm{~cm}^{-1}$ for $\mathrm{Sn}-\mathrm{O}$ vibrations [56] and peaks for $\mathrm{BaCO}_{3}$. 
Further heating causes a decrease of the $\mathrm{BaCO}_{3}$ peaks; and at $900{ }^{\circ} \mathrm{C}$ only traces of $\mathrm{BaCO}_{3}$ can be observed. Fig 6 shows the IR spectra in the range between 1000-800 $\mathrm{cm}^{-1}$, demonstrating the development of the above mentioned extra peak at $872 \mathrm{~cm}^{-1}$ and the out-of-plane vibration of $\mathrm{BaCO}_{3}\left(858 \mathrm{~cm}^{-1}\right)$ at different temperatures (Fig. 6a-c,h-j). Rapid heating up to $360{ }^{\circ} \mathrm{C}$ for $3 \mathrm{~h}$ causes a band at $872 \mathrm{~cm}^{-1}$ with a weak shoulder at $858 \mathrm{~cm}^{-1}$, only heating with $10 \mathrm{~K} / \mathrm{min}$ at $360{ }^{\circ} \mathrm{C}$ showed two bands with about the same intensity (the notation " $\infty \mathrm{K} / \mathrm{min}$ " means, that the sample was put into a muffle furnace at the indicated temperature). Rapid heating up to $380{ }^{\circ} \mathrm{C}$ leads to an increasing of the band at $872 \mathrm{~cm}^{-1}$. Further heating shows a decreasing in intensity of this band and an increasing of the band at $858 \mathrm{~cm}^{-1}$. The disappearance of the peak at $872 \mathrm{~cm}^{-1}$ at a calcination temperature of $450{ }^{\circ} \mathrm{C}$ indicated that orthorhombic $\mathrm{BaCO}_{3}$ is the only carbonate phase above $450{ }^{\circ} \mathrm{C}$. The appearance and the intensity of the extra peak at $872 \mathrm{~cm}^{-1}$ is also dependent on the dwelling time and heating rate. Fig. $6 \mathrm{c}-\mathrm{g}$ shows these facts exemplarily at a calcination temperature of $380{ }^{\circ} \mathrm{C}$. At a dwelling time of $1 \mathrm{~h}$ the intensity of the out-of-plane vibration of the intermediate oxycarbonate phase is higher than the out-of-plane mode of $\mathrm{BaCO}_{3}$. With increasing dwelling time an increase of the $\mathrm{BaCO}_{3}$ band occurs, combined with a gradual decrease of the band at $872 \mathrm{~cm}^{-1}$. Thus at a dwelling time of $10 \mathrm{~h}$ only the out-of-plane mode for $\mathrm{BaCO}_{3}$ is observed. Furthermore at lower heating rates also the amount of the formed intermediate oxycarbonate phase is lower.

$<$ Graphic 5 and $6>$

\subsubsection{XRD measurements}


Fig. 7 shows an overview of the XRD investigations on samples heated up to $1000{ }^{\circ} \mathrm{C}$. The XRD pattern of a sample calcined at $300{ }^{\circ} \mathrm{C}$ (loss of the solvate molecules) reveals the very poor crystalline nature of the resulted powder, only reflections at $2 \theta=11.5^{\circ}$, $13.2^{\circ}$ and $16.8^{\circ}$ can be detected.

Heating up to $400{ }^{\circ} \mathrm{C}$ leads to a more crystalline sample. At $400{ }^{\circ} \mathrm{C}$ the formation of orthorhombic $\mathrm{BaCO}_{3}$ (Whiterite) [57] can be observed with a strong reflexion at $2 \theta=$ $27.8^{\circ}$ and tetragonal $\mathrm{SnO}_{2}($ Cassiterite $)$ at $2 \theta=31.0^{\circ}$. The reflexion at about $2 \theta=34.6^{\circ}$ can be assigned to a tin-oxide phase, possibly indicating the appearance of orthorhombic $\mathrm{SnO}_{2}$ or tetragonal $\mathrm{SnO}$ [57]. Orthorhombic $\mathrm{SnO}_{2}$ was previously observed in high-pressure experiments, or by the production of thin films [58-61], but in 2004 Lamelas [62] could show its formation also at ambient pressure. Udawatte et al. [16] observed the appearance of orthorhombic $\mathrm{SnO}_{2}$ during the decomposition of a (Ba,Sn)-precursor produced by a modified Pechini process $[63,15]$. The formation of $\mathrm{SnO}$ could be caused by the thermal decomposition of the precursor complex leading temporarily to reducing conditions (samples heated up to about $600{ }^{\circ} \mathrm{C}$ contain elemental carbon), so that $\mathrm{Sn}^{4+}$ can be reduced to $\mathrm{Sn}^{2+}$. The diffraction reflexions at about $2 \theta=24.8^{\circ}$ and $46.4^{\circ}$ cannot be assigned to any known compounds cited in the JCPDS (Joint Committee of Powder Diffraction Standards). Possibly, these reflexions hint to an unknown barium tin intermediate oxycarbonate phase. The reflexions are broad, indicating a weakly crystalline intermediate phase, where the increasing of the underground in the XRD pattern between $2 \theta \sim 9-17^{\circ}$ should be caused by the X-ray amorphous amount in the samples. Heat treatment at $500{ }^{\circ} \mathrm{C}$ shows only reflexions for $\mathrm{BaCO}_{3}$ and $\mathrm{SnO}_{2}$, whereas the reflexions of the unknown intermediate oxycarbonate phase disappeared. Above $600{ }^{\circ} \mathrm{C}$ the development of reflexions of $\mathrm{BaSnO}_{3}$ [56] among $\mathrm{BaCO}_{3}$ and $\mathrm{SnO}_{2}$ can be observed. X-ray diffraction pattern of a sample heated at 900 ${ }^{\circ} \mathrm{C}$ for $1 \mathrm{~h}$ exhibited only the reflexions of $\mathrm{BaSnO}_{3}$. 
In Fig. 8 XRD investigations in a temperature range between $360{ }^{\circ} \mathrm{C}$ and $480{ }^{\circ} \mathrm{C}$ are shown. Rapid heating up to $360{ }^{\circ} \mathrm{C}$ for $3 \mathrm{~h}$ leads to an X-ray amorphous product, whereas a heating rate of $10 \mathrm{~K} / \mathrm{min}$ results in reflexions of $\mathrm{BaCO}_{3}$ and tin oxide phases, as well as reflexions of the above mentioned intermediate oxycarbonate phase at $2 \theta=$ $24.8^{\circ}, 34.2^{\circ}, 46.4^{\circ}, 51.2^{\circ}$ and $60.5^{\circ}$, which disappeared with increasing temperature. Heat treatment above $410{ }^{\circ} \mathrm{C}$ shows only the characteristic reflexions of $\mathrm{BaCO}_{3}$ and tinoxide phases. According to the results of the IR investigations, the appearance of the intermediate oxycarbonate phase is not only dependent on the heating temperature, but also on the dwelling time and heating rate (Fig. 8c-g). Samples which were heated at $380{ }^{\circ} \mathrm{C}$ for $1-2 \mathrm{~h}$ show reflexions of $\mathrm{BaCO}_{3}$, tin oxide phases and reflexions of the intermediate oxycarbonate phase. An increasing of the dwelling time up to $10 \mathrm{~h}$ leads to disappearing of reflexions of the intermediate oxycarbonate phase. Moreover, with decreasing heating rate reflexions of the intermediate oxycarbonate phase disappear.

\author{
$<$ Graphic 7 and $8>$
}

\title{
3.3.3. Electron energy loss spectroscopy (EELS) near the ionisation edges (ELNES)
}

EELS investigations of powders calcined at different temperatures provide further evidence for the existence of the above mentioned intermediate oxycarbonate phase. This is possible because EELS allows to characterise the chemical bonding state of materials down to a lateral resolution of 1-2 $\mathrm{nm}$ by analysing the fine structures of the relevant ionisation edges (ELNES). Such fine structure features are the edge onset, and the shape, the position and the intensity of the individual peaks, which are caused by excitations of core-shell electrons into unoccupied states above the fermi level. 
Examples of the ELNES of the O-K edge (including the $\mathrm{Sn}_{-} \mathrm{M}_{45}$ ionisation edge: increasing intensity just in front of the O-K edge) of $\left[\mathrm{Ba}\left(\mathrm{C}_{2} \mathrm{H}_{6} \mathrm{O}_{2}\right)_{4}\right]\left[\mathrm{Sn}\left(\mathrm{C}_{2} \mathrm{H}_{4} \mathrm{O}_{2}\right)_{3}\right]$ calcined at $410^{\circ} \mathrm{C}$ and $600^{\circ} \mathrm{C}$ are shown in Fig. 9 together with some standard spectra. At $410^{\circ} \mathrm{C}$ some characteristic $\mathrm{O}-\mathrm{K}$ features of those of the materials $\mathrm{SnO}_{2}$ and $\mathrm{BaCO}_{3}$ can be found as indicated by the peaks marked by dashed lines in the figure. Contrary to this, $\mathrm{BaSnO}_{3}$ exhibits a complete different O-K ELNES and we can conclude that the $410^{\circ} \mathrm{C}$ sample must contain a pre-stage of $\mathrm{BaSnO}_{3}$, i.e., an intermediate phase. Further calcination at $600^{\circ}$ leads to a complete decomposition of the intermediate as revealed by the related O-K ELNES in Fig. 9 which shows well pronounced the features of $\mathrm{SnO}_{2}$ and $\mathrm{BaCO}_{3}$ now, and can be interpreted to be a sum of both.

The overall inhomogeneous composition of the calcined powders is demonstrated by performing a series of EEL spectra along a line as shown in Fig. 10, exemplified for the $380^{\circ} \mathrm{C}$ calcined powder. Each spectrum comprises an energy loss range between 250 and $600 \mathrm{eV}$. The spectra (a) indicate particles of $\mathrm{SnO}_{2}$ which are followed by a spectrum (b) containing features of $\mathrm{SnO}_{2}$ and $\mathrm{BaCO}_{3}$ (intermediate oxycarbonate phase). A region of $\mathrm{BaCO}_{3}$ particles follows (c), and finally spectra of the intermediate oxycarbonate phase (b) were detected.

$<$ Graphic 9 and $10>$

The investigations show, that the thermal decomposition of $\left[\mathrm{Ba}\left(\mathrm{C}_{2} \mathrm{H}_{6} \mathrm{O}_{2}\right)_{4}\right]\left[\mathrm{Sn}\left(\mathrm{C}_{2} \mathrm{H}_{4} \mathrm{O}_{2}\right)_{3}\right]$ leads to the appearance of an unknown intermediate oxycarbonate phase and to the formation of $\mathrm{BaCO}_{3}$ and $\mathrm{SnO}_{2}$, which reacts to $\mathrm{BaSnO}_{3}$ at relative low temperature. The intermediate oxycarbonate phase is observed in a small temperature range between about $360-410{ }^{\circ} \mathrm{C}$, being unstable at higher temperatures and disintegrated into $\mathrm{BaCO}_{3}$ and $\mathrm{SnO}_{2}$. The simultaneous presence of $\mathrm{BaCO}_{3}$ and $\mathrm{SnO}_{2}$ 
with the intermediate oxycarbonate phase suggests, that the intermediate oxycarbonate phase is possibly a result of a side reaction by the thermal decomposition of the barium tin 1,2-ethanediolato complex. Based on the thermogravimetric weight loss in this temperature range, it can be proposed that the intermediate oxycarbonate phase has a stoichiometry close to $\mathrm{BaSnO}\left(\mathrm{CO}_{3}\right)_{2}$. The calculated weight loss for the decomposition of the barium tin 1,2-ethanediolato complexes to $\mathrm{BaSnO}\left(\mathrm{CO}_{3}\right)_{2}$ is $42.7 \%$, which is in good agreement with the observed weight loss range of about $41.3-44.2 \%$ in the temperature range of $360-410{ }^{\circ} \mathrm{C}$. The proposed formula $\mathrm{BaSnO}\left(\mathrm{CO}_{3}\right)_{2}$ can also be written as $\mathrm{BaCO}_{3} \cdot \mathrm{SnOCO}_{3}$, indicating a mixture of $\mathrm{BaCO}_{3}$ and $\mathrm{SnOCO}_{3}$. A comparison of the XRD pattern between a calcined powder at $380{ }^{\circ} \mathrm{C}$ for $2 \mathrm{~h}$ and $10 \mathrm{~h}$ (see Fig. 8) shows an increase of the intensity of the $\mathrm{BaCO}_{3}$ reflexions at a dwelling time of $10 \mathrm{~h}$ and simultaneously the disappearance of the reflexions of the intermediate oxycarbonate phase, revealing that the increase of the $\mathrm{BaCO}_{3}$ formation is caused by the decomposition of the barium tin oxycarbonate phase. Based on all collected data, we conclude that the observed transient phase is a unique oxycarbonate phase having the formula $\mathrm{BaSnO}\left(\mathrm{CO}_{3}\right)_{2}$.

\section{Conclusion}

The thermal decomposition in air of $\left[\mathrm{Ba}\left(\mathrm{C}_{2} \mathrm{H}_{6} \mathrm{O}_{2}\right)_{4}\right]\left[\mathrm{Sn}\left(\mathrm{C}_{2} \mathrm{H}_{4} \mathrm{O}_{2}\right)_{3}\right]$ precursor leads to the formation of $\mathrm{BaSnO}_{3}$ below $900{ }^{\circ} \mathrm{C}$, unlike the conventional reaction between $\mathrm{BaCO}_{3}$ and $\mathrm{SnO}_{2}$, which requires temperatures up to $1300{ }^{\circ} \mathrm{C}$. During the thermal evolution of crystalline $\mathrm{BaSnO}_{3}$ the formation of an unknown barium tin oxycarbonate intermediate phase $\left(\mathrm{BaSnO}\left(\mathrm{CO}_{3}\right)_{2}\right)$ together with extremely fine divided mixture of $\mathrm{BaCO}_{3}$ and $\mathrm{SnO}_{2}$ can be observed. As revealed by XRD, IR, and EELS investigations, the barium tin 
oxycarbonate phase exists in a small temperature range and disintegrates into $\mathrm{BaCO}_{3}$ and $\mathrm{SnO}_{2}$, which reacts to $\mathrm{BaSnO}_{3}$ finally.

\section{Acknowledgements}

Thanks are due to Prof. Dr. W. Bensch (University of Kiel) for DTA/TG-MS measurements, Dr. Th. Müller for XRD and thermoanalytic measurements and PD Dr. L. Jäger for helpful discussions. Financial support by the Deutsche Forschungsgemeinschaft (SPP 1136) is gratefully acknowledged.

\section{References}

[1] R. Vivekanandan, T. R. N. Kutty, Mater. Sci. Eng. B6 (1990) 221

[2] Z. G. Zhou, G. Zhao, M. Wei, Z. T. Zhang, Sens. Actuators 19 (1989) 71

[3] B. Ostrick, M. Fleischer, U. Hampe, H. Meixner, Sens. Actuators B44 (1997) 601

[4] S. Tao, F. Gao, X. Liu, O. T. Sorensen, Sens. Actuators B71 (2000) 223

[5] G. A. Smolensky, J. Phys. Soc. Jpn. 28 (1970) 26

[6] G. Wagner, H. Binder, Z. Allg. Anorg. Chem. 297 (1958) 328

[7] V. Müller, H. Beige, H.-P. Abicht, C. Eisenschmidt, J. Mater. Res. 19(10) (2004) 2834

[8] W. Lu, H. Schmidt, J. Eur. Ceram. Soc. 25 (2005) 919

[9] J. Cerda, J. Arbiol, R. Diaz, G. Dezanneau, J. R. Morante, Mater. Lett. 56 (2002) 131

[10] T. R. N. Kutty, R. Vivekanadan, Mat. Res. Bull. 22 (1987) 1457

[11] W. W. Coffeen, J. Am. Ceram. Soc. 36(7) (1953) 207

[12] C. P. Udawatte, M. Yoshimura, Mater. Lett. 47 (2001) 7

[13] G. Pfaff, J. Eur. Ceram. Soc. 12 (1993) 159 
[14] P. K. Gallagher, D. W. Johnson (Jr.), Thermochim. Acta 4 (1972) 283

[15] M. P. Pechini, Method of Preparing Lead and Alkaline Earth Titanates and Niobates and Coating Methods Using the Same to Form a Capacitor. U.S. Pat. No. 3.330.697, 1967.

[16] C. P. Udawatte, M. Kakihana, M. Yoshimura, Solid State Ionics 108 (1998) 23

[17] L. Jäger, V. Lorenz, T. Müller, H.-P. Abicht, M. Rössel, H. Görls, Z. Anorg. Allg. Chem. 630 (2004) 189

[18] R. Köferstein, L. Jäger, V. Lorenz, H.-P. Abicht, J. Woltersdorf, E. Pippel, H. Görls, Solid State Sci. 7 (2005)1280

[19] H. S. Gopalakrishnamurthy, M. S. Rao, T. R. N. Kutty, J. Inorg. Nucl. Chem. 37 (1975) 891

[20] O. O. Vasyl'kin, A. V. Ragulya, V. V. Skorokhod, Powder Metallurgy and Metal Ceramics 36 (1997) 277

[21] D. Hennings, W. Mayr, J. Solid State Chem. 26 (1978) 329

[22] J.-D. Tsay, T.-T. Fang, T. A. Gubiotti, J. Y. Ying, J. Mater. Sci. 33 (1998) 3721

[23] M. Arima, M. Kakihana, Y. Nakamura, M. Yashima, M. Yoshimura, J. Am. Ceram. Soc. 79(11) (1996) 2847

[24] W.-S. Cho, J. Phys. Chem. Solids. 59 (1998) 659

[25] S. Tangwiwat, S. J. Milne, J. Non-Cryst. Solids 351 (2005) 976

[26] M. Rajendran, M. S. Rao, J. Solid State Chem. 113 (1994) 239

[27] S. Kumar, G. L. Messing, W. B. White, J. Am. Ceram. Soc. 76(3) (1993) 617

[28] S. Gablenz, H.-P. Abicht, E. Pippel, O.Lichtenberger, J. Woltersdorf, J. Eur. Ceram. Soc. 20 (2000) 1053

[29] P. Duran, D. Gutierrez, J. Tartaj, M. A. Banares, C. Moure, J. Eur. Ceram. Soc. 22 (2002) 797 
[30] P. Duran, F. Capel, T. Tartaj, D. Gutierrez, C. Moure, Solid State Ionics 141-142 (2001) 529

[31] R. Liedtke, S. Hoffmann, R. Waser, J. Am. Ceram. Soc. 83(2) (2000) 436

[32] U. Hasenkox, S. Hoffmann, R. Waser, J. Solid-Gel Sci. Technol. 12 (1998) 67

[33] E. R. Leite, C. M. G. Sousa, E. Longo, J. A. Varela, Ceramics International 21 (1995) 143

[34] A. Glasner, M. Steinberg, J. Inorg. Nucl. Chem. 16 (1961) 279

[35] A. Glasner, M. Steinberg, J. Inorg. Nucl. Chem. 22 (1961) 39

[36] J. O. Sawyer, P. Caro, L. Eyring, Monatshefte Chemie 102 (1971) 333

[37] R. P. Turcotte, J. O. Sawyer, L. Eyring, Inorg. Chem. 8(2) (1969) 238

[38] E. Krupicka, A. Reller, A. Weidenkaff, Crystal Engineering 5 (2002) 195

[39] D. Dillomore, D. Nicholson, J. Chem. Soc. (1962) 960

[40] V. V Subba Rao, R. V. G. Rao, A. B. Biswas, J. Inorg. Nucl. Chem. 28 (1966) 415

[41] S. J. Gregg, J. Chem. Soc. (1953) 3940

[42] G. Tammann, Q. A. Mansuri, Z. Anorg. Allg. Chem. 126 (1922) 119

[43] G. Tammann, A. Sworykin, Z. Anorg. Allg. Chem. 176 (1928) 46

[44] G. Tammann, Z. Angew. Chem. 29 (1926) 869

[45] G. Tammann, Z. Anorg. Allg. Chem. 157 (1926) 321

[46] G. F. Hüttig, Kolloid-Zeitschrift 98 (1942) 263

[47] G. F. Hüttig, Kolloid-Zeitschrift 99 (1942) 262

[48] P. Buckley, P.A. Giguere, Can. J. Chem. 45 (1967) 397

[49] D. Knetsch, W. L. Groeneveld, Inorg. Chim. Acta 7(1) (1973) 81

[50] H. Frei, Tae-Kuy HA, R. Meyer, Hs. H. Günthard, Chem. Phys. 25 (1977) 271

[51] H. Matsuura, T. Miyazawa, Bull. Chem. Soc. Japan 40 (1967) 85

[52] T. Takeuchi, M. Tasumi, Chem. Phys.77 (1983) 21 
[53] L. Pellerito, G. Ruisi, R. Barbieri, Inorg. Chim. Acta 32 (1979) 39

[54] F. K. Butcher, W. Gerhard, E. F. Mooney, R. G. Rees, H. A. Willis, Spectrochim. Acta 20 (1964) 51

[55] K. Nakamoto, Infrared and Raman Spectra of Inorganic and Coordination Compounds, John Wiley \& Sons, USA, 1986

[56] Gmelin, Handbuch der Anorganischen Chemie, Zinn C3, 8. Auflage, SpringerVerlag, Berlin-Heidelberg-New York, 1975

[57] PDF 2 (International Centre for Diffraction Data, Pensylvania) $\mathrm{BaCO}_{3}$ [5-378],

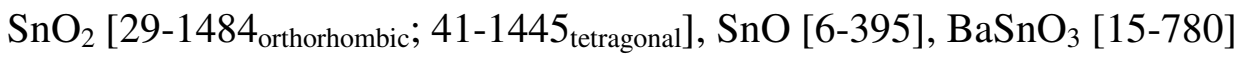

[58] D. M. Adams, A. G. Christy, J. Haines, S. M. Clark, Phys. Rev. B 46(11) (1992) 358

[59] K. Suito, N. Kawai, Y. Masuda, Mater. Res. Bull. 10 (1975) 677

[60] E. Müller, Acta Cryst. B 40 (1984) 359

[61] F. J. Lamelas, S. A. Reid, Phys. Rev. B 60(13) (1999) 9347

[62] F. J. Lamelas, J. Appl. Phys. 96(11) (2004) 6195

[63] M. Kakihana, J. Sol-Gel Sci. Technol. 6 (1996) 7 


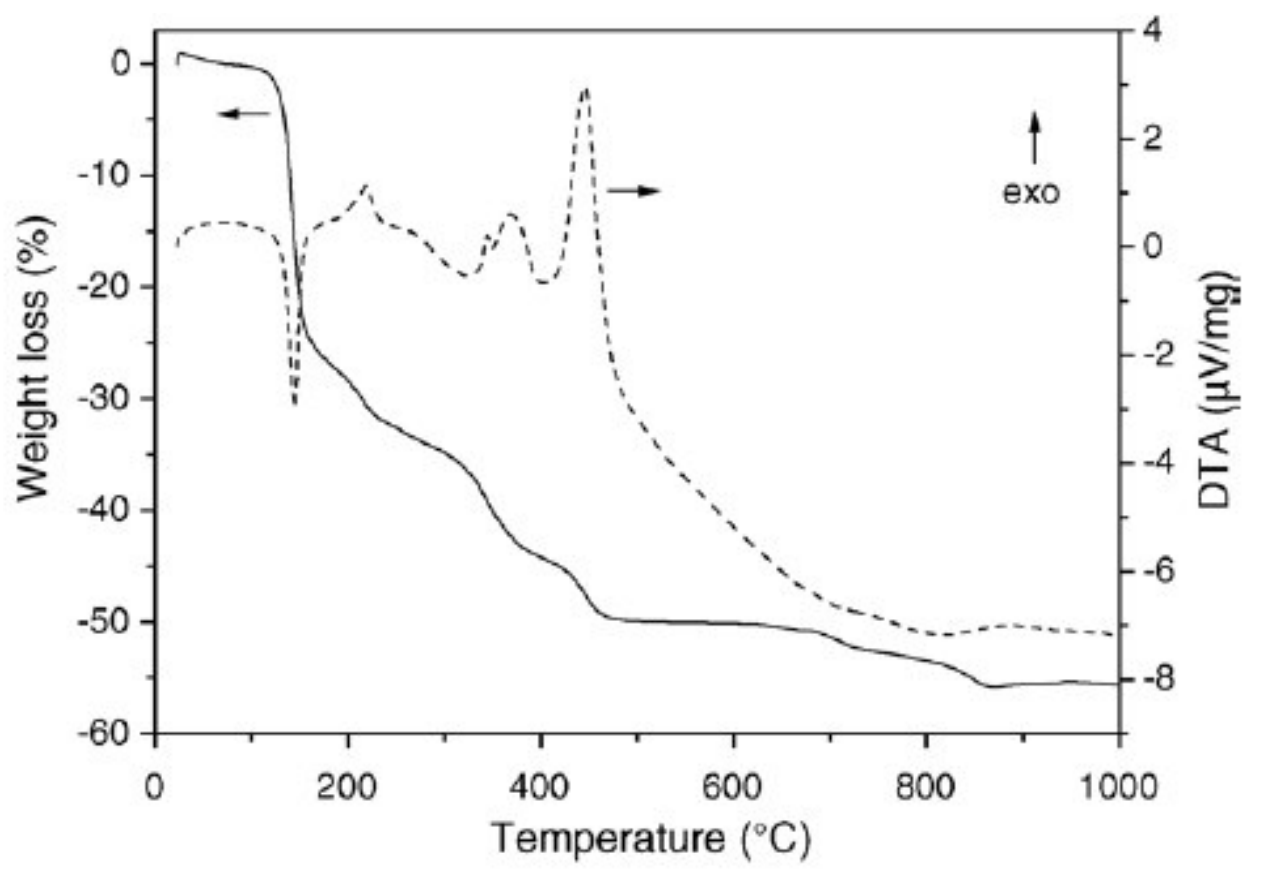

Fig. 1. TG/DTA curves of $\left[\mathrm{Ba}\left(\mathrm{C}_{2} \mathrm{H}_{6} \mathrm{O}_{2}\right)_{4}\right]\left[\mathrm{Sn}\left(\mathrm{C}_{2} \mathrm{H}_{4} \mathrm{O}_{2}\right)_{3}\right]$ in air.

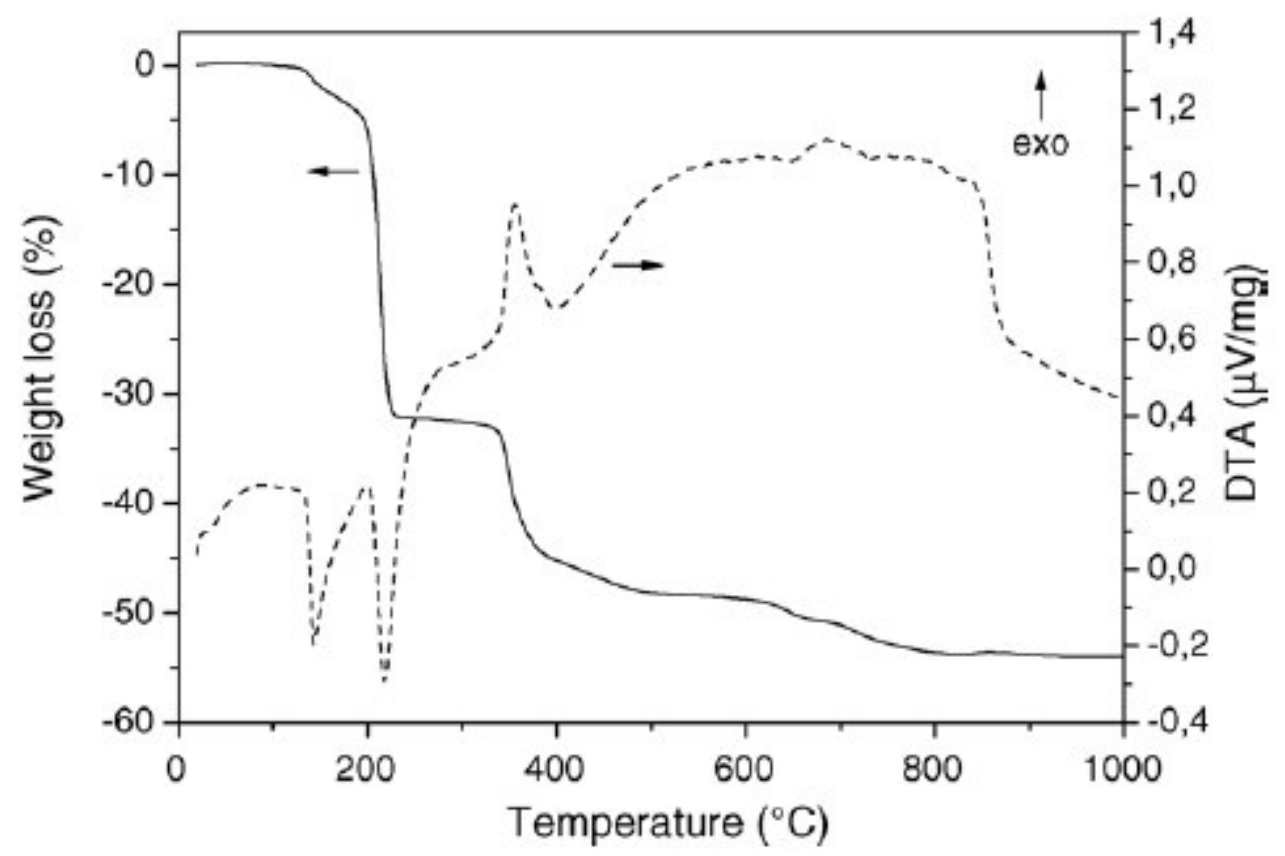

Fig. 2. TG/DTA curves of $\left[\mathrm{Ba}\left(\mathrm{C}_{2} \mathrm{H}_{6} \mathrm{O}_{2}\right)_{4}\right]\left[\mathrm{Sn}\left(\mathrm{C}_{2} \mathrm{H}_{4} \mathrm{O}_{2}\right)_{3}\right]$ in argon. 


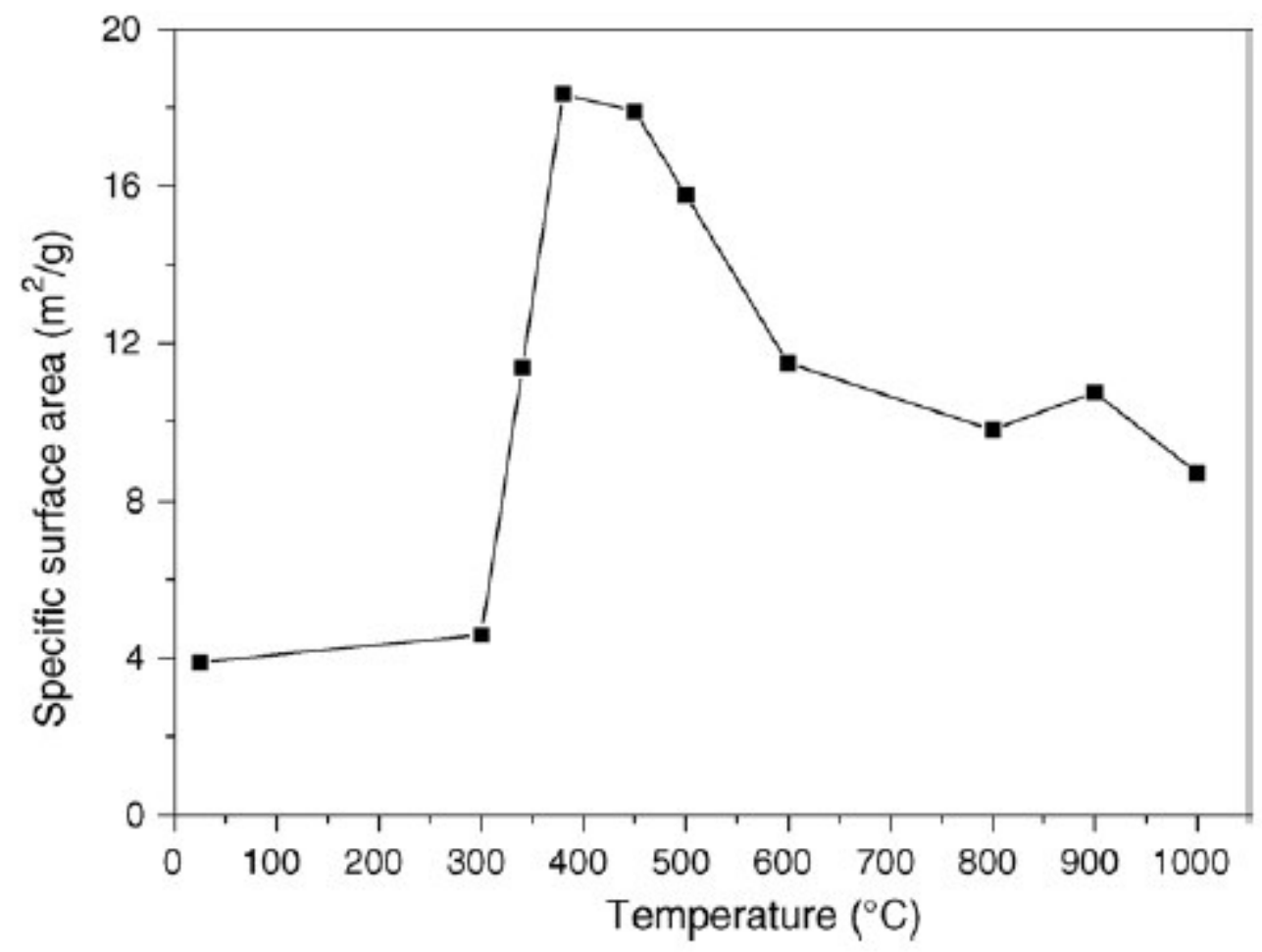

Fig. 3. Specific surface area vs. calcination temperature of $\left[\mathrm{Ba}\left(\mathrm{C}_{2} \mathrm{H}_{6} \mathrm{O}_{2}\right)_{4}\right]\left[\mathrm{Sn}\left(\mathrm{C}_{2} \mathrm{H}_{4} \mathrm{O}_{2}\right)_{3}\right]$ (heating rate, $10 \mathrm{~K} / \mathrm{min}$; dwelling time, $1 \mathrm{~h})$. 


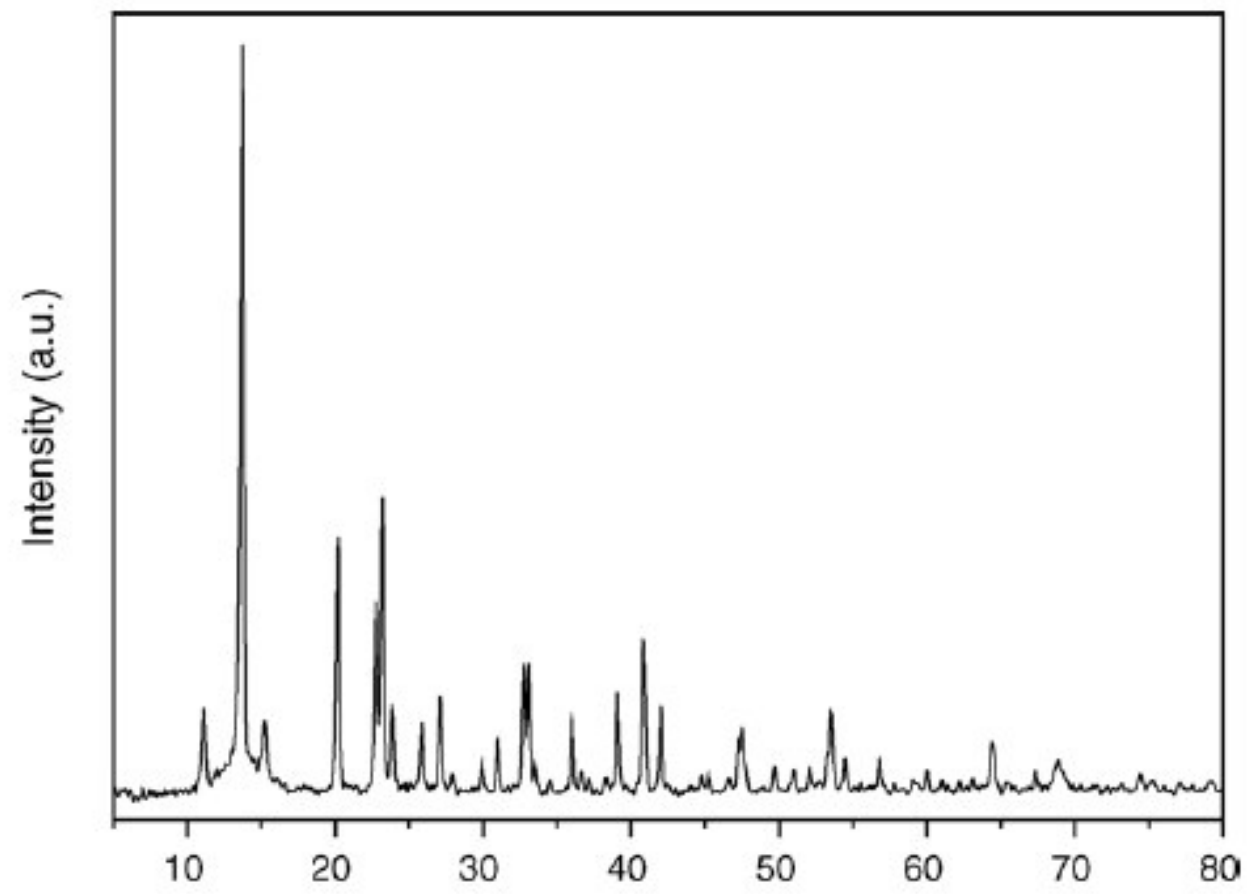

(a)

$2 \theta\left({ }^{\circ}\right)$

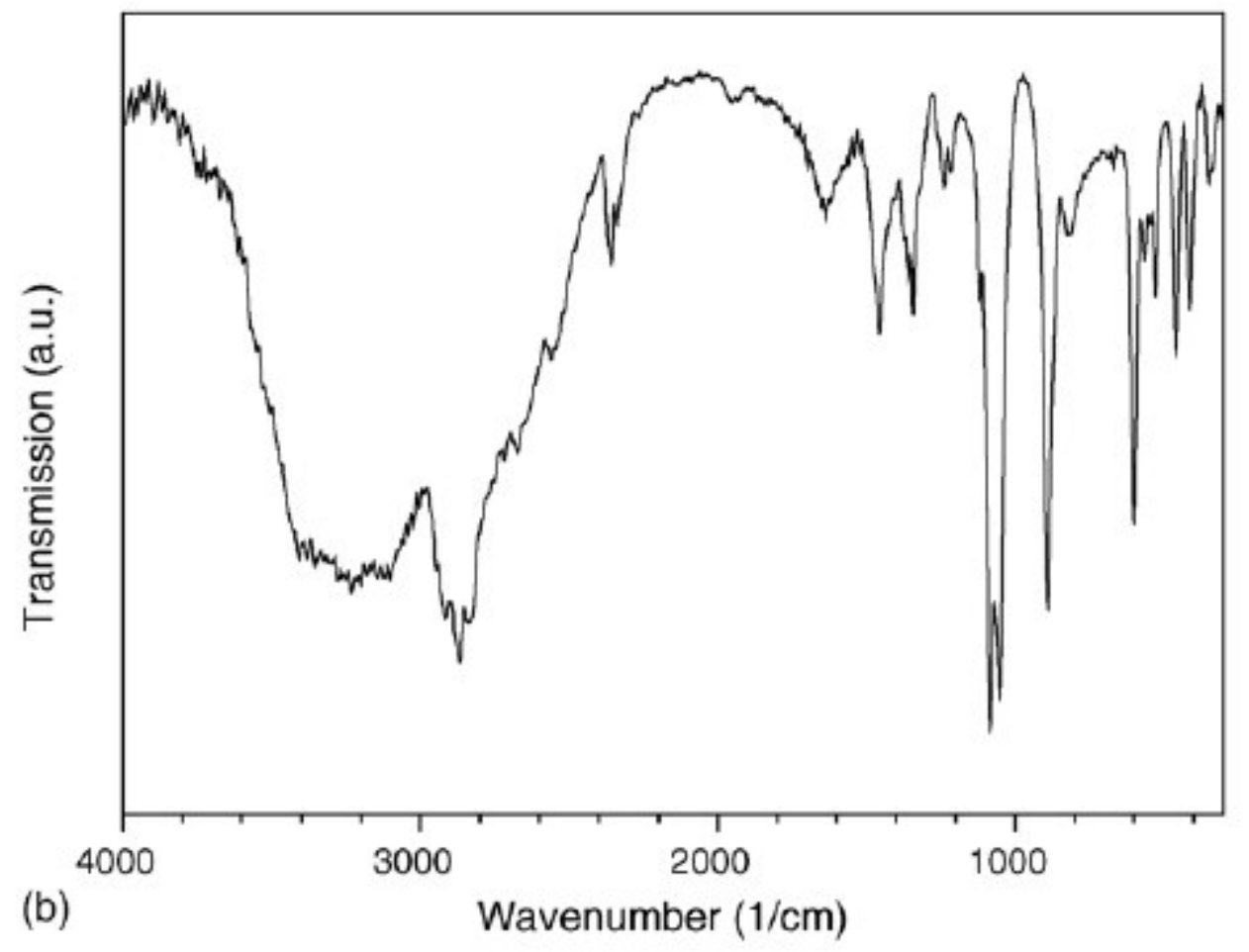

Fig. 4. XRD pattern (a) and IR spectrum (b) of $\left[\mathrm{Ba}\left(\mathrm{C}_{2} \mathrm{H}_{6} \mathrm{O}_{2}\right)_{4}\right]\left[\mathrm{Sn}\left(\mathrm{C}_{2} \mathrm{H}_{4} \mathrm{O}_{2}\right)_{3}\right]$. 


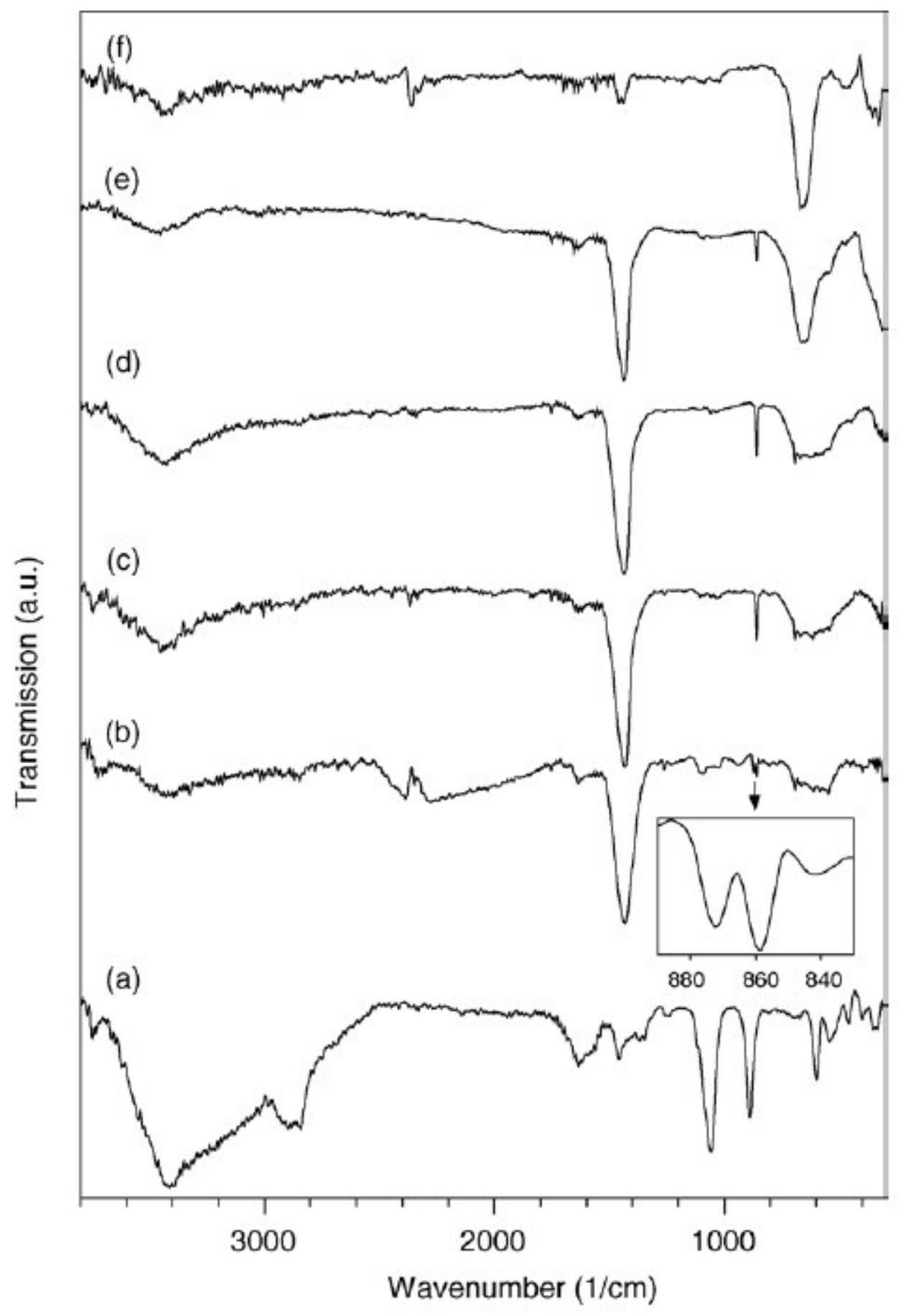

Fig. 5. IR spectra of decomposition products of $\left[\mathrm{Ba}\left(\mathrm{C}_{2} \mathrm{H}_{6} \mathrm{O}_{2}\right)_{4}\right]\left[\mathrm{Sn}\left(\mathrm{C}_{2} \mathrm{H}_{4} \mathrm{O}_{2}\right)_{3}\right]$ at various temperatures (heating rate, $10 \mathrm{~K} / \mathrm{min}$; dwelling time, $1 \mathrm{~h}$ ): (a) $300^{\circ} \mathrm{C}$; (b) $400^{\circ} \mathrm{C}$; (c) $500^{\circ} \mathrm{C}$; (d) $600^{\circ} \mathrm{C}$; (e) $800^{\circ} \mathrm{C}$; (f) $900^{\circ} \mathrm{C}$. The inset in (b) shows an enlargement of the range between 890 and $830 \mathrm{~cm}^{-1}$. Spectra $(\mathrm{b}-\mathrm{f})$ show a weak broad band at $\sim 3000 \mathrm{~cm}^{-1}$ due to water absorbed by the $\mathrm{KBr}$ powder. 


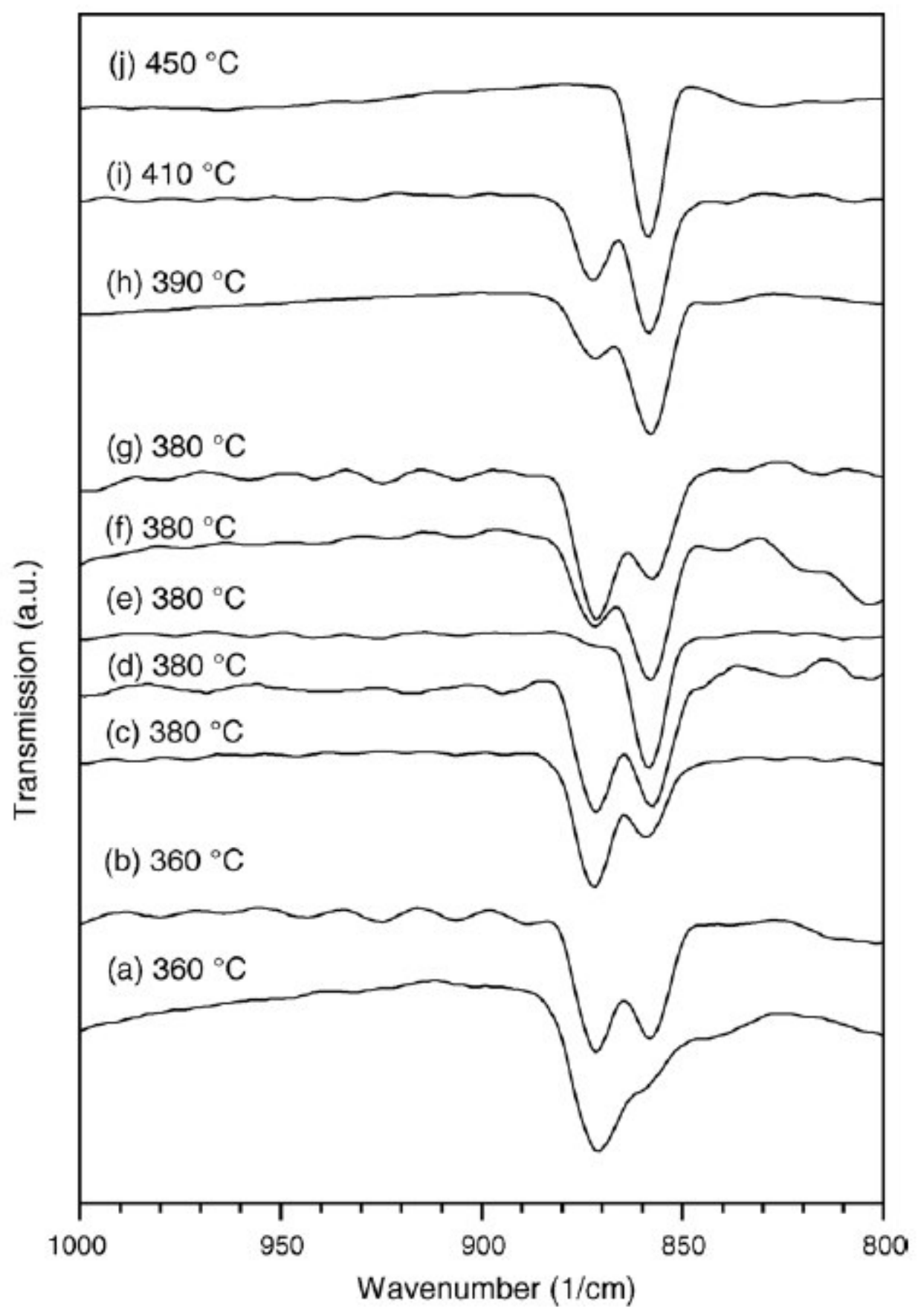

Fig. 6. IR spectra of $\left[\mathrm{Ba}\left(\mathrm{C}_{2} \mathrm{H}_{6} \mathrm{O}_{2}\right)_{4}\right]\left[\mathrm{Sn}\left(\mathrm{C}_{2} \mathrm{H}_{4} \mathrm{O}_{2}\right)_{3}\right]$ powders calcined at the indicated temperatures (different dwelling times and heating rates: (a) $3 \mathrm{~h}$, $\infty \mathrm{K} / \mathrm{min}$; (b, c, h-j) $1 \mathrm{~h}, 10 \mathrm{~K} / \mathrm{min}$; (d) $2 \mathrm{~h}, 10 \mathrm{~K} / \mathrm{min}$; (e) $10 \mathrm{~h}, 10 \mathrm{~K} / \mathrm{min}$; (f) $1 \mathrm{~h}, 1 \mathrm{~K} / \mathrm{min}$; (g) $1 \mathrm{~h}, \infty \mathrm{K} / \mathrm{min}$ ). The notation " $\infty \mathrm{K} / \mathrm{min}$ " means that the sample was put into a muffle furnace at the indicated temperature. 


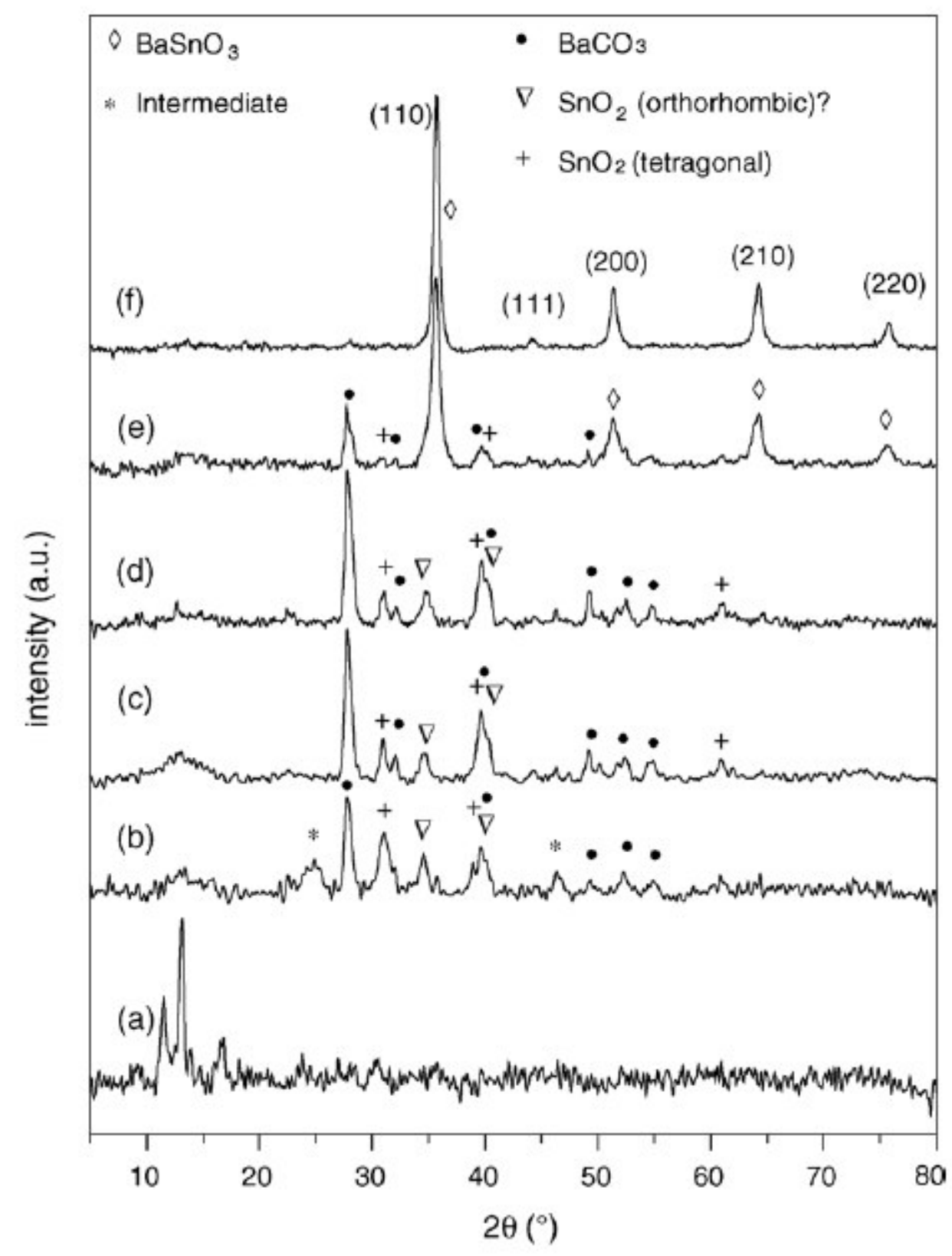

Fig. 7. $\mathrm{XRD}$ patterns of $\left[\mathrm{Ba}\left(\mathrm{C}_{2} \mathrm{H}_{6} \mathrm{O}_{2}\right)_{4}\right]\left[\mathrm{Sn}\left(\mathrm{C}_{2} \mathrm{H}_{4} \mathrm{O}_{2}\right)_{3}\right]$ powders calcined at various temperatures (heating rate, $10 \mathrm{~K} / \mathrm{min}$; dwelling time, $1 \mathrm{~h}$ ): (a) $300^{\circ} \mathrm{C}$; (b) $400^{\circ} \mathrm{C}$; (c) $500^{\circ} \mathrm{C}$; (d) $600^{\circ} \mathrm{C}$; (e) $800^{\circ} \mathrm{C}$; (f) $900^{\circ} \mathrm{C}$. 


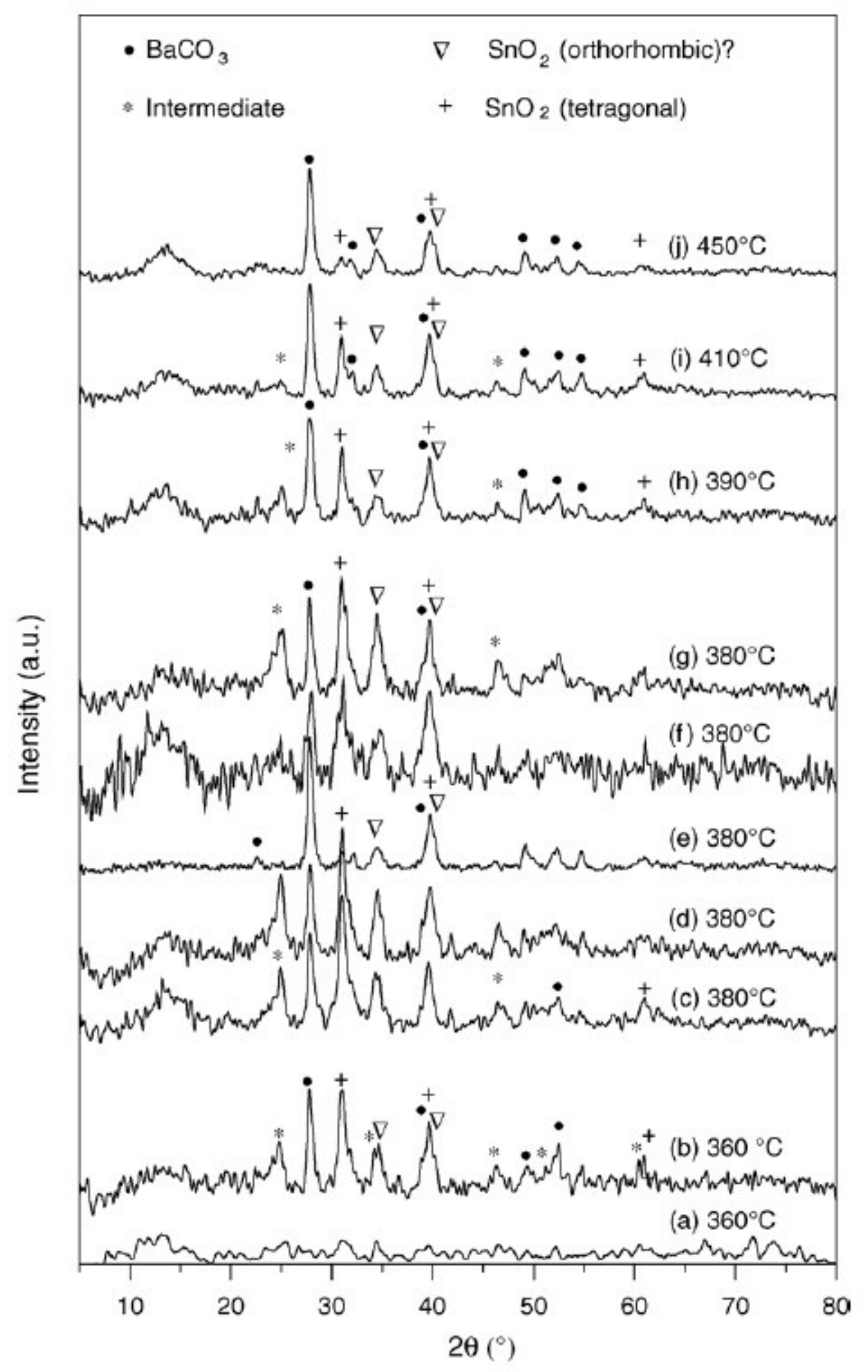

Fig. 8. XRD patterns of $\left[\mathrm{Ba}\left(\mathrm{C}_{2} \mathrm{H}_{6} \mathrm{O}_{2}\right)_{4}\right]\left[\mathrm{Sn}\left(\mathrm{C}_{2} \mathrm{H}_{4} \mathrm{O}_{2}\right)_{3}\right]$ powders calcined at the indicated temperatures (different dwelling times and heating rates: (a) $3 \mathrm{~h}$, $\infty \mathrm{K} / \mathrm{min}$; (b, c, h-j) $1 \mathrm{~h}, 10 \mathrm{~K} / \mathrm{min}$; (d) $2 \mathrm{~h}, 10 \mathrm{~K} / \mathrm{min}$; (e) $10 \mathrm{~h}, 10 \mathrm{~K} / \mathrm{min}$; (f) $1 \mathrm{~h}$, $1 \mathrm{~K} / \mathrm{min}$; (g) $1 \mathrm{~h}, \infty \mathrm{K} / \mathrm{min}$ ). 


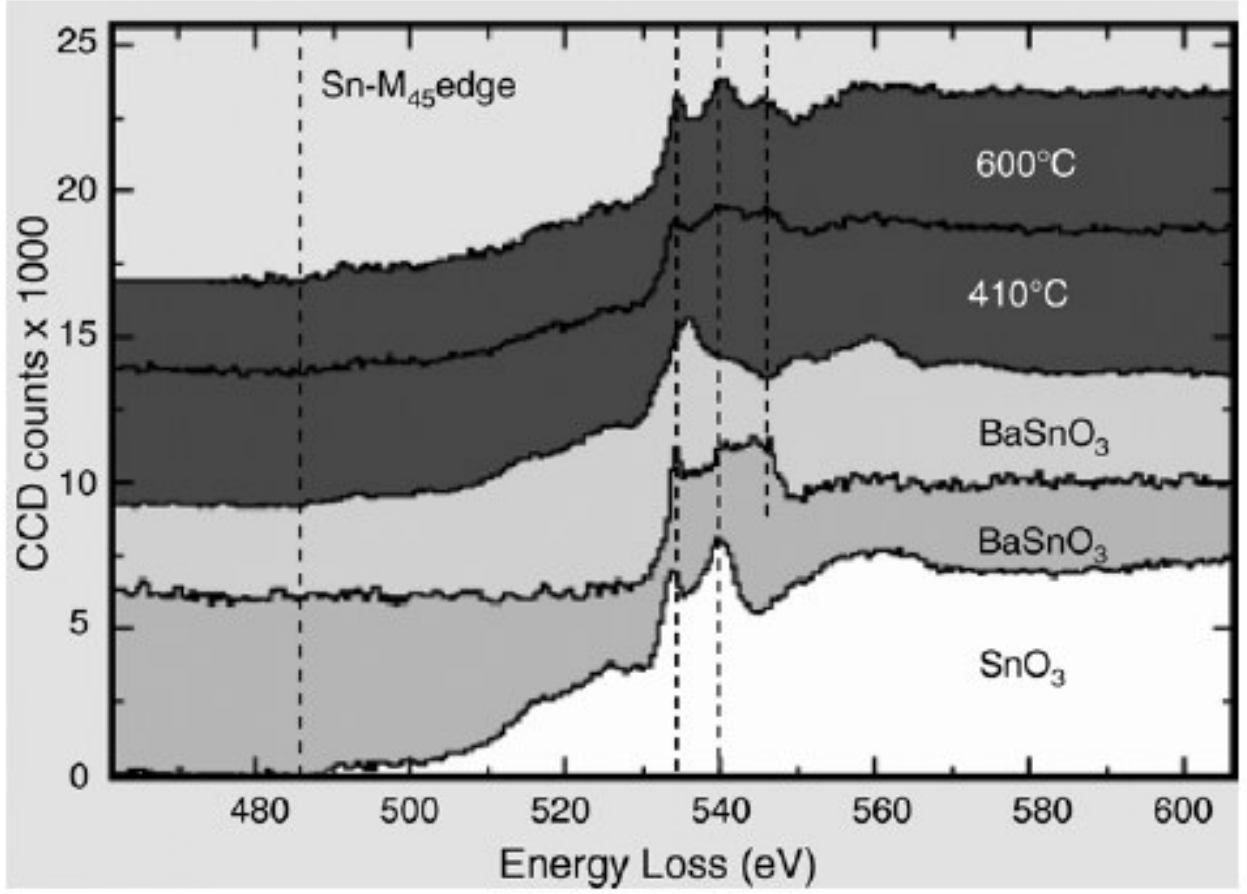

Fig. 9. ELNES of the $\mathrm{O}-\mathrm{K}$ edge (and $\mathrm{Sn}-\mathrm{M}_{45}$ ) of barium tin(IV) 1,2ethanediolato complexes calcined at 410 and $600^{\circ} \mathrm{C}$, and of $\mathrm{BaSnO}_{3}, \mathrm{BaCO}_{3}$ and $\mathrm{SnO}_{2}$ standards.

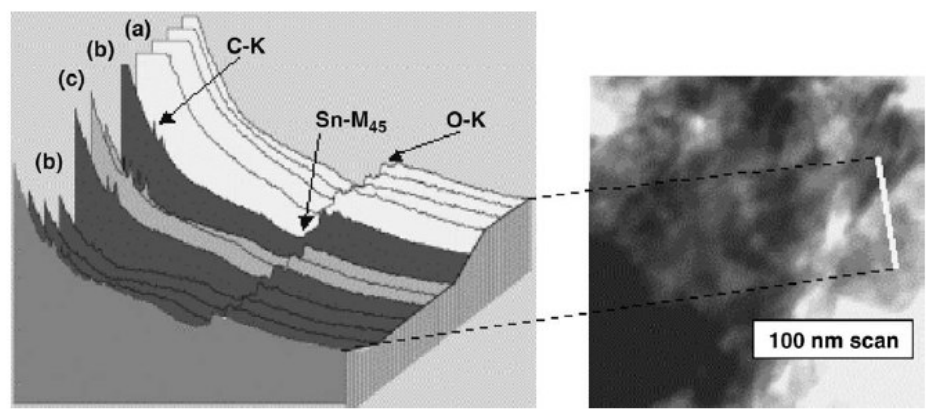

Fig. 10. Series of EEL spectra across a powder (right: STEM image with line of analysis) of a barium tin(IV) 1,2-ethandiolato complex calcined at $380^{\circ} \mathrm{C}$ for $2 \mathrm{~h}$ (a) $\mathrm{SnO}_{2}$; (b) intermediate oxycarbonate phase; (c) $\mathrm{BaCO}_{3}$-rich area. 